\title{
Katarzyna Sornat
}

DOI: 10.33896/PorJ.2019.10.6

(Uniwersytet Warszawski,

e-mail: k.sornat@o2.pl)

\section{SLOWA MIESIACACA ROKU 2018 W POLACH LEKSYKALNO-SEMANTYCZNYCH}

Zgodnie $z$ tytułem artykułu zostana $\mathrm{w}$ nim przedstawione wyniki analizy leksykalno-semantycznej tzw. słów miesiąca, czyli wyrazów (rzadziej ich połączeń), które w ciagu dwunastu miesięcy danego roku osiągnęły zwiększoną frekwencję w polskiej prasie codziennej. ${ }^{1}$ Pod względem metodologicznym przeprowadzone badania wpisuja się w nurt językoznawstwa strukturalnego w ujęciu synchronicznym. Podczas analizy zgromadzonego materiału wykorzystano narzędzia nowoczesnej lingwistyki korpusowej oraz „tradycyjna” klasyfikację pól wyrazowych. Na potrzeby rozprawy $z$ cyklicznych podsumowań zamieszczanych $\mathrm{w}$ każdym miesiącu 2018 roku przez zespół językoznawczy na stronie www. slowanaczasie.uw.edu.pl (w zakładce: słowa miesiaca) wyekscerpowano 71 leksemów ${ }^{2}$ użytych łącznie 78 razy. ${ }^{3}$ Tak pozyskane wyrazy umiesz-

1 Na wstępie wymaga zaznaczenia, że wbrew tradycyjnemu ujęciu słów miesiąca, za które polscy badacze na ogół uznają tylko jeden wyraz (jedno wyrażenie) danego miesiąca, w niniejszej rozprawie do słów miesiaca 2018 roku zalicza się wszystkie jednostki leksykalne opisane przez językoznawców w comiesięcznych podsumowaniach, zamieszczonych na podanej stronie [Derwojedowa, Kopcinska, Kwiecień, Łaziński 2018, Słowa miesiaca, Uniwersytet Warszawski, dostęp: 26.03.2019, <http://www.slowanaczasie.uw.edu.pl/category/slowanaczasie/ slowa-miesiaca/>].

${ }^{2} \mathrm{~W}$ artykule terminu leksem używa się wymiennie $\mathrm{z}$ nazwa jednostka leksykalna, przez która $z$ kolei rozumie się taki element podsystemu leksykalnego, „który nie daje się dalej podzielić według kryterium semantycznego, to znaczy taki, który istnieje w tym podsystemie jako najmniejsza całość znaczeniowa" [Markowski 2012, 30]. Jak zatem wynika $z$ powyższego, każdemu z 71 wyekscerpowanych słów miesiąca przyporządkowano tylko jedno znaczenie. Wyrazy wielokształtne przytacza się tu zgodnie $z$ ich oryginalnym zapisem na stronie Słów na czasie, tj. w postaci inwariantów fleksyjnych tych jednostek (np. niepetnosprawni, kamizelki, premie, ale samorzadowy).

3 Kilka słów osiągnęło zwiększoną frekwencję więcej niż w jednym miesiącu (tzn. w dwóch lub trzech miesiącach), por. tab. 1. 
czono następnie w odpowiednich, ustalonych kontekstowo polach i podpolach tematycznych. ${ }^{4}$

W tekstach referatów wygłoszonych dotąd podczas kilku konferencji i sympozjów o zasięgu krajowym (Warszawa, Torun 2015) oraz międzynarodowym (Warszawa 2016, 2018) językoznawcy z różnych ośrodków naukowych w Polsce - m.in. z Warszawy, Wrocławia, Łodzi - zawarli interesujące tezy, które w kontekście podjętych tu analiz warto sprawdzić. A zatem według wyników badań Marka Łazińskiego pod względem tematycznym słowa miesiąca w latach 2012-2015 najczęściej dotyczyły polityki, ekonomii i życia społecznego (34 wystapienia), rzadziej natury (6 wystapień), a jeszcze rzadziej religii (4 wystapienia) oraz sportu (3 wystapienia) [Łaziński 2015a, 14]. O cyklach frekwencyjnych niektórych wyrazów i wyrażeń wypowiadał się Piotr Pęzik, który zwrócił uwagę na zjawisko ich stałej sezonowości (powtarzalności) w każdym roku kalendarzowym [Pęzik 2015]. Konstrukcję kategorii czasu w odniesieniu do tego typu słownictwa badał również Adam Pawłowski. Wrocławski językoznawca wskazywał z kolei na cykliczność warunkujacca periodyczne ukazywanie się pewnych leksemów w prasie codziennej, w związku z czym wyróżnił on czas linearny i czas kolisty, a w obrębie tego ostatniego - czas astronomiczny, polityczny oraz kulturowy [Pawłowski 2015, 6].

\section{SLOWA DNIA, MIESIĄCA, TYGODNIA, ROKU - KRÓTKI RYS HISTORYCZNY}

Badaniem statystyki tzw. słów dnia, miesiąca, roku językoznawcy z Instytutu Języka Polskiego UW zajmuja od 2011 r. Ponad dekadę wcześniej - w 2000 r. - zespół Marka Łazińskiego rozpoczął sprawdzanie frekwencji słów tygodnia. Początkowo analiza zestawień tygodniowych obejmowała wyłącznie wydanie „Rzeczpospolitej” i w latach 2000-2005 była prowadzona przez redakcję tegoż dziennika w porozumieniu $z$ zespołem Korpusu Języka Polskiego (KJPPWN), a następnie $z$ Narodowym Korpusem Języka Polskiego (NKJP). W 2010 r. badania częstości słów $\mathrm{w}$ polskiej prasie rozszerzono na cztery największe dzienniki krajowe. ${ }^{5}$ Od 2011 r. (tj. od chwili zakończenia projektu NKJP) badacze $z$ Instytutu Języka Polskiego UW, przy stałym wsparciu informatyków, śledzą

4 Określenia pole leksykalno-semantyczne, pole semantyczne, pole znaczeniowe, pole tematyczne, pole językowe, pole wyrazowe występuja w pracy zamiennie. Przyjmujac za A. Markowskim, „pole leksykalne (i jego synonimy) to uporządkowana wewnętrznie grupa wyrazów, które są powiązane znaczeniowo" [Markowski 2012, 14].

5 Tj. „Dziennik. Gazetę Prawna”, „Gazetę Wyborcza”, „Polska. The Times” oraz „Rzeczpospolita” [Łaziński 2015b, 3]. 
i opisują słownictwo artykułów prasowych. Słowa miesiąca zespół M. Łazińskiego wybiera regularnie od 2012 r. (komentowanie wybranych jednostek wprowadzono rok później). Słowa dnia publikowane są codziennie na stronach: http://slowadnia.clarin-pl.eu oraz https://www.facebook. com/SlowaDnia. ${ }^{6}$ Jak już wspomniano, tygodniowe podsumowania słów dnia, słowa miesiąca i słowa roku ${ }^{7}$ można odnaleźć na stronie: slowanaczasie.uw.edu.pl, po otwarciu odpowiednich zakładek (podstron). Bezpośrednia inspiracja do podjęcia tego typu badań w Polsce stał się projekt „Wortschatz” i „Wörter des Tages” pracowników Uniwersytetu Lipskiego, którzy od 2002 r. na oficjalnej stronie internetowej zamieszczaja tzw. słowa dnia, ustalane na podstawie wydań sieciowych najważniejszych tytułów prasowych i serwisów informacyjnych w Niemczech [Laziński 2015b, 1-4].8

Jak twierdzi M. Łaziński: „monitorowanie częstości słów wskazuje słowa i tematy, które w danym dniu lub dłuższym okresie ogniskuja uwagę mediów i społeczeństwa" [Łaziński 2015b, 4]. Celem artykułu jest prezentacja wyników analizy leksykalno-semantycznej słów miesiacca 2018 roku, które to wyniki nie tylko pozwoliły ustalić listę tematów najbardziej zajmujacych Polaków od stycznia do grudnia minionego roku, lecz także umożliwiły weryfikację niektórych wniosków wysuwanych do tej pory przez badaczy słów cyklicznych.

6 Codziennie rano językoznawcy z Instytutu Języka Polskiego UW wraz $z$ Piotrem Pęzikiem $z$ Uniwersytetu Łódzkiego porównuja frekwencję słów $z$ kanałów RSS wiadomości prasowych siedmiu gazet ogólnopolskich, gdyż do tytułów wymienionych wcześniej dołaczyły jeszcze „Nasz Dziennik”, „Fakt” i „Super Express". Cytaty i wykresy częstości słów dnia sa wyszukiwane przez serwis frazeo.pl, a do ich obliczeń wykorzystuje się tzw. miarę kluczowości statystycznej Dunninga [Derwojedowa, Kopcińska, Łaziński, Pęzik 2015, Słowa dnia, dostęp: 26.03.2019, <http://slowadnia.clarin-pl.eu/\#/default/1834>].

7 W odróżnieniu od słów dnia, tygodnia i miesiąca, których ważność jest ustalana na podstawie statystyki, słowa roku wybiera kapituła językoznawców, a od 2014 r. oddzielnie robia to także internauci. O wyborze danego hasła na słowo roku decyduje głównie oryginalność semantyczna i/lub retoryczna wyrazu, a także jego aktualność i „świeżość” w medialno-społecznym przekazie. Dane frekwencyjne maja w tym wypadku znaczenie drugorzędne, co najwyżej pomocnicze [Łaziński 2015b, 17].

8 Projekt „Wortschatz” obejmuje także niezrównoważony korpus języka niemieckiego (liczacy 425 mln słów), korpusy rosyjski i angielski oraz sieciowy słownik języka niemieckiego [tamże, 2]. 


\section{STRUKTURA TEMATYCZNA SEÓW MIESIĄCA 2018 ROKU}

Głównym celem analizy było umieszczenie 71 słów miesiaca w polach leksykalno-semantycznych wybranych klasyfikacji. Jak podkreśla A. Markowski, kryteria wydzielania pól znaczeniowych mogą być różne. „Zestawianie pól, ustalanie ich liczby i szczegółowość zależą od przyjętych rozwiazań teoretycznych. Możliwe sa dwa zasadnicze podejścia" - pisze autor Leksyki wspólnej różnym odmianom polszczyzny [Markowski 2012, 108]. Jednym $z$ nich jest podzielenie całej rzeczywistości na określone sfery pojęciowe, a następnie konstruowanie odpowiadających tym sferom pól wyrazowych. ${ }^{10} \mathrm{~W}$ niniejszej pracy zdecydowano się na ów podział „odgórny”, dzięki któremu ostatecznie „otrzymujemy pewna, zwykle dość dużą, liczbę szczegółowych pól leksykalnych” [tamże, 108]. Zanim jednak umieszczono wyekscerpowane słownictwo w 12 polach i 28 podpolach znaczeniowych, uprzednio zbadano kontekst najczęstszych wystapień tych jednostek w ubiegłorocznym przekazie medialnym. ${ }^{11}$ Takie postępowanie pozwoliło ograniczyć do minimum badawczy subiektywizm, przed którym przestrzega przywołany wyżej leksykolog [Markowski 2012, 108]. Zawarte w tekście informacje ilustruje poniższa tabela:

9 Ze względu na aktualność nazewnictwa zastosowanego przez A. Markowskiego w podziale polowym współczesnego słownictwa wspólnoodmianowego nazwy podpól tematycznych wzorowano na tymże schemacie [Markowski 1990/1, 252-253]. W celach praktycznych przyjęta siatkę pojęciowa uzupełniono o nazwy pól w opracowaniu S. Dubisza [Dubisz 2002, 134-140]. W razie wątpliwości związanych $z$ porządkowaniem zgromadzonego materiału pomocniczo korzystano również $\mathrm{z}$ układu polowego prezentowanego w Wielkim słowniku języka polskiego [WSJP 2007-].

10 Drugie $z$ rozwiazań opisanych przez A. Markowskiego polega na znajdowaniu wspólnych elementów znaczeniowych wśród wyrazów powiąanych semantycznie i łączeniu tych jednostek w minipola językowe, grupowane następnie w większe pola i sfery, aż do zapełnienia nimi całej rzeczywistości językowej [Markowski 2012, 108].

$11 \mathrm{Na}$ tym etapie analizy korzystano $\mathrm{z}$ informacji zamieszczonych na stronie Słów na czasie [dostęp: 26.03.2019, <www.slowanaczasie.uw.edu.pl>], a także z serwisu Słowa dnia [dostęp: 26.03.2019, <http: / slowadnia.clarin-pl.eu>] oraz wyszukiwarki Frazeo.pl [dostęp: 26.03.2019, <http://frazeo.pl/>]. 
Tabela 1. Stowa miesiąca 2018 roku w polach i podpolach leksykalno-semantycznych. Wykaz szczegółowy

\begin{tabular}{|c|c|c|c|}
\hline $\begin{array}{c}\text { Pola i podpola } \\
\text { leksykalno-semantyczne }\end{array}$ & $\begin{array}{c}\text { liczba } \\
\text { wystapień } \\
(\%)\end{array}$ & $\begin{array}{l}\text { nazwy } \\
\text { miesięcy }\end{array}$ & $\begin{array}{l}\text { stowa miesiaca / } \\
\text { miejsce na lišcie pod } \\
\text { względem frekwencji }\end{array}$ \\
\hline I $<$ Ciało człowieka $>$ & $\begin{array}{c}4 \\
(5,1 \%)\end{array}$ & \multicolumn{2}{|c|}{ 4. miejsce (ex aequo) } \\
\hline $\begin{array}{l}\text { 1. <działanie ciała, zmysły, } \\
\text { choroby> }\end{array}$ & 2 & $\begin{array}{l}\text { kwiecień } \\
\text { maj }\end{array}$ & niepełnosprawni $(2)^{12}$ \\
\hline $\begin{array}{l}\text { 2. <dbałość o ciało, higiena, } \\
\text { leczenie, wypoczynek> }\end{array}$ & 1 & sierpień & parasol \\
\hline 3. <bieg życia, rozwój ciała> & 1 & marzec & aborcja \\
\hline II <Psychika człowieka $>$ & $\begin{array}{c}1 \\
(1,3 \%)\end{array}$ & \multicolumn{2}{|c|}{ 7. miejsce (ex aequo) } \\
\hline $\begin{array}{l}\text { 4. <rozum, pamięć, wyobraźnia } \\
\text { i ich oceny> }\end{array}$ & 1 & luty & pamięć \\
\hline III $<$ Życie codzienne człowieka $>$ & $\begin{array}{c}3 \\
(3,8 \%)\end{array}$ & \multicolumn{2}{|c|}{ 5. miejsce (ex aequo) } \\
\hline 5. <ubranie, materiały, ozdoby> & 2 & $\begin{array}{l}\text { sierpień } \\
\text { grudzień }\end{array}$ & kamizelki, koszulka \\
\hline 6. <stosunki rodzinne> & 1 & maj & opiekun \\
\hline $\begin{array}{l}\text { IV < Artystyczna działalność } \\
\text { człowieka> }\end{array}$ & $\begin{array}{c}1 \\
(1,3 \%)\end{array}$ & \multicolumn{2}{|c|}{ 7. miejsce (ex aequo) } \\
\hline 7. <teatr, film> & 1 & wrzesień & Kler \\
\hline V <Człowiek w społeczności $>$ & $\begin{array}{c}22 \\
(28 \%)\end{array}$ & \multicolumn{2}{|l|}{ 2. miejsce } \\
\hline 8. <stosunki międzyludzkie> & 3 & $\begin{array}{l}\text { styczeń } \\
\text { luty } \\
\text { marzec }\end{array}$ & $\begin{array}{l}\text { Holokaust, ratunek, } \\
\text { otrucie }\end{array}$ \\
\hline 9. <stosunki ogólnospołeczne> & 3 & $\begin{array}{l}\text { lipiec } \\
\text { listopad }\end{array}$ & $\begin{array}{l}\text { afera, marsz, } \\
\text { spoczynek }\end{array}$ \\
\hline 10. <zwyczaje i obyczaje> & 7 & $\begin{array}{l}\text { kwiecień } \\
\text { maj } \\
\text { listopad } \\
\text { grudzień }\end{array}$ & $\begin{array}{l}\text { Boże Narodzenie, } \\
\text { choinka, majówka } \\
\text { (2), obchody, Święta, } \\
\text { Wigilia }\end{array}$ \\
\hline 11. <rozrywka, zabawa> & 3 & $\begin{array}{l}\text { styczeń } \\
\text { grudzień }\end{array}$ & $\begin{array}{l}\text { juwenalia, orkiestra, } \\
\text { Sylwester }\end{array}$ \\
\hline
\end{tabular}

12 Oznaczenia cyfrowe w nawiasach wskazuja na liczbę wystapień jednostek, które powtarzały się na liście słów miesiąca 2018 roku. 
cd. tabeli 1.

\begin{tabular}{|c|c|c|c|}
\hline $\begin{array}{c}\text { Pola i podpola } \\
\text { leksykalno-semantyczne }\end{array}$ & $\begin{array}{c}\text { liczba } \\
\text { wystapien } \\
(\%)\end{array}$ & $\begin{array}{l}\text { nazwy } \\
\text { miesięcy }\end{array}$ & $\begin{array}{l}\text { stowa miesiaca / } \\
\text { miejsce na liście pod } \\
\text { względem frekwencji }\end{array}$ \\
\hline 12. <sport wyczynowy> & 6 & $\begin{array}{l}\text { styczeń } \\
\text { czerwiec } \\
\text { wrzesień }\end{array}$ & $\begin{array}{l}\text { himalaista, mistrz, } \\
\text { mundial, piłkarz, } \\
\text { siatkówka, skoczek }\end{array}$ \\
\hline VI < Wiedza człowieka $>$ & $\begin{array}{c}3 \\
(3,8 \%)\end{array}$ & \multicolumn{2}{|c|}{ 5. miejsce (ex aequo) } \\
\hline 13. <szkoła i wychowanie> & 3 & $\begin{array}{l}\text { kwiecień } \\
\text { maj } \\
\text { czerwiec }\end{array}$ & $\begin{array}{l}\text { gimnazjalny, matura, } \\
\text { student }\end{array}$ \\
\hline $\begin{array}{l}\text { VII <Człowiek a instytucja } \\
\text { państwa }>\end{array}$ & $\begin{array}{c}24 \\
(31 \%)\end{array}$ & \multicolumn{2}{|l|}{ 1. miejsce } \\
\hline 14. <urząd, państwo, polityka> & 16 & $\begin{array}{l}\text { luty } \\
\text { marzec } \\
\text { kwiecień } \\
\text { maj } \\
\text { sierpień } \\
\text { wrzesień } \\
\text { październik } \\
\text { listopad }\end{array}$ & $\begin{array}{l}\text { dane, dyplomata, } \\
\text { nadzór, kandydat } \\
\text { (2), koalicja } \\
\text { (2), konwencja, } \\
\text { niepodległość, } \\
\text { nowelizacja, radny, } \\
\text { RODO, samorzad, } \\
\text { samorzadowy, } \\
\text { wybory (2) }\end{array}$ \\
\hline 15. <wojsko> & 2 & $\begin{array}{l}\text { marzec } \\
\text { sierpień }\end{array}$ & degradacja, defilada \\
\hline 16. $<$ sad $>$ & 2 & lipiec & sad, sędzia \\
\hline 17. <własnośćc & 4 & $\begin{array}{l}\text { marzec } \\
\text { listopad } \\
\text { grudzień }\end{array}$ & $\begin{array}{l}\text { bonifikata, } \\
\text { odzyskanie, premie, } \\
\text { użytkowanie } \\
\text { wieczyste }\end{array}$ \\
\hline $\begin{array}{l}\text { VIII <Otoczenie cywilizacyjne } \\
\text { człowieka }>\end{array}$ & $\begin{array}{c}4 \\
(5,1 \%)\end{array}$ & \multicolumn{2}{|c|}{ 4. miejsce (ex aequo) } \\
\hline 18. <miasto i jego części> & 4 & $\begin{array}{l}\text { kwiecień } \\
\text { maj } \\
\text { październik }\end{array}$ & $\begin{array}{l}\text { budowa } \\
\text { miasto (3) }\end{array}$ \\
\hline IX < Praca człowieka> & $\begin{array}{c}2 \\
(2,5 \%)\end{array}$ & \multicolumn{2}{|l|}{ 6. miejsce } \\
\hline 19. <handel i usługi> & 1 & marzec & handel \\
\hline 20. <gospodarka> & 1 & maj & kopalnia \\
\hline $\mathrm{X}<$ Człowiek a astronomia $>$ & $\begin{array}{c}4 \\
(5,1 \%)\end{array}$ & \multicolumn{2}{|c|}{ 4. miejsce (ex aequo) } \\
\hline
\end{tabular}


cd. tabeli 1.

\begin{tabular}{|c|c|c|c|}
\hline $\begin{array}{c}\text { Pola i podpola } \\
\text { leksykalno-semantyczne }\end{array}$ & $\begin{array}{c}\text { liczba } \\
\text { wystąpien } \\
\text { (\%) }\end{array}$ & $\begin{array}{l}\text { nazwy } \\
\text { miesięcy }\end{array}$ & $\begin{array}{l}\text { stowa miesiaca / } \\
\text { miejsce na liście pod } \\
\text { względem frekwencji }\end{array}$ \\
\hline 21. <niebo i gwiazdy> & 1 & lipiec & zaćmienie \\
\hline 22. <pogoda> & 3 & $\begin{array}{l}\text { sierpień } \\
\text { grudzień }\end{array}$ & $\begin{array}{l}\text { klimat, klimatyczny, } \\
\text { upat }\end{array}$ \\
\hline XI <Człowieka a przyroda $>$ & $\begin{array}{c}5 \\
(6,5 \%)\end{array}$ & \multicolumn{2}{|c|}{ 3. miejsce (ex aequo) } \\
\hline $\begin{array}{l}\text { 23. <ziemia, przyroda } \\
\text { nieożywiona> }\end{array}$ & 2 & $\begin{array}{l}\text { lipiec } \\
\text { listopad }\end{array}$ & cieśnina, jaskinia \\
\hline 24. <rośliny i bakterie> & 1 & lipiec & sinice \\
\hline 25. <zwierzęta> & 2 & $\begin{array}{l}\text { czerwiec } \\
\text { lipiec }\end{array}$ & pyton tygrysi, foka \\
\hline $\begin{array}{l}\text { XII <Człowiek a imponderabilia } \\
\text { bytu> }\end{array}$ & $\begin{array}{c}5 \\
(6,5 \%)\end{array}$ & \multicolumn{2}{|c|}{ 3. miejsce (ex aequo) } \\
\hline 26. cechy materii & 1 & kwiecień & chemiczny \\
\hline 27. <przestrzeń> & 1 & kwiecień & smoleński \\
\hline 28. $<$ czas $>$ & 3 & $\begin{array}{l}\text { marzec } \\
\text { październik } \\
\text { listopad }\end{array}$ & Marzec, rocznica, tura \\
\hline Ogólem: 12 pól, 28 podpól & 78 & & \\
\hline
\end{tabular}

Źródło: oprac. własne.

Przed omówieniem wniosków $\mathrm{z}$ analizy jakościowej materiału należy powtórzyć, że niektóre $z$ wyodrębnionych jednostek uznano za słowa ważne częściej niż tylko w jednym miesiącu, w związku $z$ czym łączna liczba wystapień tych 71 leksemów wyniosła nie 71 , lecz 78 razy w całym roku. Najczęściej, trzykrotnie, słowem miesiąca 2018 ogłoszono miasto, którego zwiększona frekwencja w kwietniu, maju i październiku ma związek $z$ nagłośniona w tych miesiącach kampanią samorządową. Ta ostatnia przyczyniła się również do częstszej niż zwykle obecności w mediach rzeczowników wybory, koalicja i kandydat - słów sierpnia $i$ września (kandydat) oraz września i października (koalicja, wybory). Dwukrotnie też był nim obierany leksem niepełnosprawni (IV, V), jako jedyny reprezentujący w ogólnym zestawieniu podpole 1 . <działanie ciała, zmysły, choroby> i za każdym razem pojawiajacy się w kontekście protestu, który wiosna 2018 r. w gmachu Sejmu podjęli opiekunowie tych osób. Przykładem cykliczności pewnych wyrazów, których zwiększoną frekwencję językoznawcy odnotowuja co roku o tej samej porze, jest ma- 
jówka - słowo kwietnia i, rzecz jasna, maja. Warto dodać, że słownik ogólny języka polskiego [USJP 2003] ów rzeczownik zalicza do odmiany potocznej współczesnej polszczyzny (w znaczeniu 'wiosenna wycieczka za miasto'). Niegdyś kojarzona głównie $z$ zabawami tanecznymi w plenerze, dziś majówka to dla Polaków przede wszystkim przypadające na początek maja święta oraz przed-i/lub poświąteczny weekend. ${ }^{13} \mathrm{Z}$ tej racji za właściwe uznano umieszczenie omawianego leksemu nie w podpolu 11. <rozrywka, zabawa>, lecz w podpolu 10. <zwyczaje, obyczaje>, obok innych nazw „świattecznych”, równie cyklicznych jak wiosenna majówka (por. XII - Boże Narodzenie, XII - choinka, XI - obchody, XII - Święta, XII - Wigilia). W wypadku pozostałych słów miesiaca zarejestrowano ich jednorazowe wystapienie.

Na ogół językoznawcy sa zgodni co do tego, że w zbiorze leksyki o zwiększonej frekwencji daje się zauważyć stała powtarzalność niektórych słów, zwiazanych albo $z$ pora roku, albo $z$ wydarzeniami społecznymi, które regularnie odbywaja się w tym samym czasie. Potwierdzenie przytoczonej tezy można odnaleźć już wśród słów stycznia 2018 roku. $Z$ zima - tu konkretnie $z$ dyscyplinami sportu uprawianymi w sezonie zimowym - łacza sie tematycznie wyrazy himalaista oraz skoczek, oba przyporzadkowane do podpola 12 . <sport wyczynowy>. Cyklicznie w styczniowym przekazie prasowym pojawia się też rzeczownik orkiestra (albo Orkiestra), który na przestrzeni ostatnich lat wyraźnie rozszerzył swoje znaczenie za sprawa działalności Wielkiej Orkiestry Świątecznej Pomocy (WOŚP) i co najmniej od dekady w pierwszym miesiącu każdego roku występuje najczęściej w kontekście imprezy rozrywkowo-medialnej. ${ }^{14}$ Jedynie słowo ratunek zarejestrowano w styczniu 2018 okazjonalnie (zwykle w połączeniu $z$ omówionym wcześniej himalaista), a do jego wzmożonej frekwencji przyczyniła się nieudana wówczas wyprawa polskich wspinaczy na Nanga Parbat.

Luty 2018 roku uplyną na wspomnieniach przykrych dla naszego narodu wydarzeń $z$ przeszłości. Wśród słów miesiąca tym razem pojawiło się również proprium Holokaust, dotąd najczęściej opisywane w kontekście ludobójstwa Żydów. W lutym symbolicznie zaznaczyła swoją obecność pamięć o tej tragedii - jedyny w wykazie ogólnym leksem $z$ pola $<$ Psychiki człowieka>. Okazjonalny charakter należy też przypisać nazwie nowelizacja, która w lutym 2018 r. często występowała w zwiąku $z$ wywołującymi kontrowersje zmianami w ustawie o Instytucie Pamięci Narodowej (IPN). Wspólny element znaczeniowy tych trzech rzeczowników (czyli 'przeszłość') pozwala je ze sobą łączyć, mimo że na ogół te

13 Chodzi o święta: 1 Maja i Konstytucji 3 Maja oraz łączący je Dzień Flagi. Por. Derwojedowa [3.06.2017, Słowo maja: majówka, dostep: 26.03.2019, <http:/ / www.slowanaczasie.uw.edu.pl/slowo-maja-majowka/>].

14 Derwojedowa [14.01.2018, Jak co roku w połowie stycznia Orkiestra, dostęp: 26.03.2019, <http://www.slowanaczasie.uw.edu.pl/jak-co-roku-w-polowie-stycznia-orkiestra/>]. 
wyrazy reprezentuja nie tyko inne pola tematyczne (por. tab. 1.), lecz także różne odmiany stylistyczne i profesjonalne współczesnej polszczyzny: ksiażk. Holokaust, og. pamięć oraz praw. nowelizacja [USJP 2003].

W marcu 2018 roku społeczna pamięć Polaków o historii po raz kolejny znalazła odzwierciedlenie w jednym ze słów o zwiększonej frekwencji. Tym razem była nia nazwa własna Marzec, odnoszaca się bezpośrednio do „tego” marca z 1968 roku i przez wzgląd na swoja pierwotna temporalność ('nazwa miesiąca') wraz z październikowa tura (druga tura wyborów samorządowych) i listopadową rocznica (setna rocznica odzyskania niepodległości) znalazła się w podpolu 28. <czas>. O tym, że niechlubna przeszłość nie daje o sobie zapomnieć nawet po kilkudziesięciu latach świadczy obecność wśród marcowych słów miesiąca rzeczownika degradacja. Dużą frekwencję tego wyrazu w mediach w tym okresie należy tłumaczyć wprowadzeniem ustawy degradacyjnej pozbawiającej stopni wojskowych osoby, które w latach 1943-1990 sprzeniewierzyły się polskiej racji stanu. ${ }^{15}$ Tematyczny zwiazek degradacji $z$ wojskiem sprawił, że razem $z$ sierpniowa, cykliczna defilada (defilada $z$ okazji święta Wojska Polskiego) oba rzeczowniki umieszczono w polu $<$ Człowiek a instytucja państwa>, w podpolu 15. <wojsko>. Bardziej jednak niż przeszłość sprzed półwiecza w trzecim miesiącu zajmowała nas aktualna sytuacja społeczno-polityczna, zarówno w kraju (aborcja 'projekt ustawy zaostrzajacej prawo aborcyjne', handel 'zakaz handlu w niedzielę', premie 'dla rządu'), jak i za granica (otrucie 'próba otrucia podwójnego rosyjsko-brytyjskiego szpiega', dyplomaci 'wydalenie rosyjskich dyplomatów $z$ Wielkiej Brytanii jako konsekwencja tego zamachu').

W kwietniu wystapiły słowa cykliczne, których powtarzalność motywowana była przede wszystkim zmiennością czasu kulturowego, antropologicznego [Pawłowski 2015, 6]. Wśród kwietniowych słów miesiąca tym razem zarejestrowano aż trzy przymiotniki. Pierwszy z nich - wyraz gimnazjalny - należy łączyć $z$ wydarzeniem dydaktycznym odbywającym się w polskich szkołach zawsze o tej porze (gimnazjalny 'o egzaminie'). Druga $z$ nazw przymiotnikowych ma wymiar społeczno-polityczny (smoleński) i od kilku lat $z$ wiadomych przyczyn (katastrofa samolotowa w Smoleńsku) regularnie w czwartym miesiącu roku osiaga zwiększoną frekwencję $\mathrm{w}$ rodzimych mediach. Trzeci przymiotnik, leksem chemiczny, w kwietniu 2018 r. odnosił się do okazjonalnego ataku chemicznego w Syrii, ogniskującego wówczas uwage polskiego społeczeństwa nie mniej niż wspomniana tragedia smoleńska. $Z$ tą ostatnia wiąże się również kwietniowy rzeczownik budowa (uroczyste odsłonięcie pomnika ofiar katastrofy na placu Piłsudskiego), który razem $z$ omówionym uprzednio miastem repre-

15 Wilgocki [6.03.2018, „Sejm przyjął ustawę degradacyjną. Jest adresowana do rodzin żołnierzy wyklętych”, Wyborcza.pl, dostęp: 29.03.2019, http:/ / wyborcza.pl/7,75398,23108490,sejm-przyjal-ustawe-degradacyjna.html?disableRedirects $=$ true $>$. 
zentuje w ogólnym zestawieniu tematycznym podpole $18 .<$ miasto i jego części>. Najwidoczniej zbliżające się majowe święta zajmują Polaków już kilka tygodni wcześniej, skoro cykliczna majówkę ogłoszono zarówno słowem maja, jak i kwietnia 2018 roku. W tych samych miesiącach częściej niż inne wyrazy rejestrowano też w przekazach informacyjnych rzeczownik niepełnosprawni, który w kwietniu i w maju ubiegłego roku przeważnie występował w połączeniu $z$ innym słowem maja $-\mathrm{tj} . \mathrm{z}$ opiekunem. Warto dodać, że okazjonalność charakteryzuje również wystapienie wśród słów kwietnia leksemu radny, który jako jedyny w tym podzbiorze pochodzi $z$ pola <Człowiek a instytucja państwa>, a konkretnie: $z$ najliczniejszego w całym wykazie 16-elementowego podpola 14 . <urząd, państwo, polityka> (por. tab. 1.).

Maj 2018 tradycyjnie upłynął w kontekście matury, która każdego roku przez niemal cały miesiąc przyciaga uwagę Polaków, bez względu na ich wiek czy wykształcenie. Po raz kolejny słowami miesiąca językoznawcy $z$ Instytutu Języka Polskiego UW ogłosili miasto i niepelnosprawnych oraz od kwietnia wyczekiwana przez wszystkich majówkę. Wraz z niepelnosprawnymi przed budynkiem Sejmu na Wiejskiej w piatym miesiacu ubiegłego roku wytrwale strajkowali ich opiekunowie, co też sprawiło, że jednym ze słów maja ustanowiono właśnie rzeczownik opiekun. Cyklicznie porą majową studenci $z$ różnych miast świętują studenckie juwenalia, które ze względu na rozrywkowy charakter tej imprezy reprezentuja $\mathrm{w}$ opracowanym wykazie (razem $z$ sylwestrem i omawiana już orkiestra) „społeczne” podpole 11 . <rozrywka, zabawa>. Inne słowa maja to wyrazy okazjonalne, a ich wystapienie w zbiorze słów miesiąca łączy się z jednostkowymi wydarzeniami, którymi żyła wówczas cała Polska. Te słowa to kopalnia (wypadek w kopalni „Zofiówka”), wymieniane wcześniej RODO (Rozporządzenie o Ochronie Danych Osobowych) oraz blisko zwiazany z tym skrótowcem rzeczownik dane.

W kolejnych tygodniach to piłkarskie wydarzenia sportowe zdominowały - zwłaszcza w drugiej połowie czerwca - przekaz medialny w kraju i za granicą. Odbywające się wówczas w Rosji mistrzostwa świata w piłce nożnej wpłynęły na to, że spośród pięciu słów czerwca aż trzy $z$ nich: mistrz, mundial i piłkarz tematycznie reprezentuja podpole 12 . <sport wyczynowy>. Pozostałe dwa leksemy o największej frekwencji zarejestrowanej w tym miesiącu pochodza $z$ podpól 13. <szkoła i wychowanie> oraz 25. <zwierzęta>. Jak wyjaśnia ich obecność w zbiorze słów czerwca Magdalena Derwojedowa: „Student trafił do czołówki ze względu na protesty na uczelniach, foka - przez bestialsko zabite zwierzęta znajdowane nad Bałtykiem". ${ }^{16}$

Lipiec 2018 roku sprzyjał anomaliom ze świata natury, które bezpośrednio skutkowały zwiększoną frekwencją słów $z$ kręgu $<$ Człowiek

16 Derwojedowa [1.07.2018, Słowo czerwca: mistrz, dostęp: 26.03.2019, <http://www.slowanaczasie.uw.edu.pl/slowo-czerwca-mistrz/>]. 
a przyroda>. Oprócz tajemniczego pytona tygrysiego, rzekomo pływającego w podwarszawskim Konstancinie, poruszenie wywołały też toksyczne sinice w Zatoce Gdańskiej, które, rozprzestrzeniwszy się na całe wybrzeże, skutecznie zakłóciły letni wypoczynek rzeszom turystów przebywajacych w tym czasie nad Bałtykiem. W lipcu media na całym świecie (w Polsce także) częściej niż zwykle notowały słowo jaskinia, a to za sprawa prowadzonej przez kilkanaście dni lipca głośnej akcji ratunkowej chłopców uwięzionych w tajlandzkiej grocie. W siódmym miesiącu 2018 roku doszło ponadto do zaćmienia Księżyca (por. zaćmienie), zjawiska astronomicznego, które emocjonowało wówczas mieszkańców kraju nad Wisłą na równi $z$ wydarzeniami społeczno-politycznymi. $Z$ tymi ostatnimi ściśle łączą się rzeczowniki spoczynek, sad i sędzia, kolejne słowa miesiąca, które w odróżnieniu od poprzednich leksemów „przyrodniczych" reprezentuja podpola 9. <stosunki ogólnospołeczne> oraz 14 . $<$ urząd, państwo, polityka>. Ich częsta obecność w lipcowej prasie codziennej była wywołana burzliwymi dyskusjami dotyczacymi przeniesienia w stan spoczynku sędziów Sądu Najwyższego (najczęstsze konteksty: dyskusje o sędziowskim stanie spoczynku, stan spoczynku w zawodzie sędziowskim oraz przeniesienie w stan spoczynku sędziów $\mathrm{SN}^{17}$ ).

W drugim miesiącu wakacji oprócz wyrazu upał, ${ }^{18}$ który cyklicznie powraca na listy frekwencyjne w zwiazku $z$ wysoka (tym razem rekordowa) temperatura powietrza typowa dla tej pory roku, słowem sierpnia była defilada. Warto dodać, że jest to rzeczownik pochodzenia francuskiego (fr. défilade, [WSWO 2017, 246]), pojawiający się w sierpniowych czołówkach prasowych w kontekście uroczystych obchodów święta Wojska Polskiego. Jak jednak informuje autorka podsumowania słów sierpnia 2018 roku, tym razem defilada rozbudziła w narodzie jeszcze więcej dyskusji i emocji. ${ }^{19}$ Italianizmem wśród wyrazów o „największej kluczowości" w ósmym miesiącu był parasol (wł. parasole, [WSJP 2007-]), który latem najczęściej chroni Polaków przed palącym słońcem. Natomiast zupełnie w innym znaczeniu niż „ochronnym” czy „ubraniowym” pojawiał się w sierpniowych przekazach leksem koszulka. Chociaż razem $z$ grudniowa kamizelka reprezentuje on podpole tematyczne 5 . <ubranie, materiały, ozdoby>, to jednak kontekst wystapień koszulki w badanym okresie ('pomniki i rzeźby w koszulkach z napisem „Konstytucja”') sprawił, że słowo to nabrało znaczenia symbolicznego i, podobnie jak francuska (żółta) kamizelka, stało się wyrazem obywatelskiego sprze-

17 Słowa dnia. Spoczynek [dostęp: 29.03. 2019, <http://slowadnia.clarin-pl. $\mathrm{eu} / \# /$ search/spoczynek/true>].

18 Najczęściej w połaczeniach: afrykańskie, tropikalne, letnie, ogromne upały, fala upałów, upały doskwieraja, walczyć z upałami; zob. Słowa dnia. Upał [dostęp: 29.03.2019, http://slowadnia.clarin-pl.eu/\#/search/upa\%C5\%82/true>].

19 Derwojedowa [4.09.2018, Stowo sierpnia: defilada (+ parasol), dostęp: 29.03.2019, <http://www.slowanaczasie.uw.edu.pl/slowo-sierpnia-defiladaparasol/>]. 
ciwu wobec władzy. ${ }^{20}$ Ostatnim słowem sierpnia jest kandydat, wyraz książkowy pochodzenia łacińskiego (łac. candidatus, [USJP 2003]), którego zwiększoną frekwencję w sierpniu i we wrześniu 2018 roku motywowało nadchodzace wydarzenie cykliczne o charakterze politycznym - październikowe wybory samorzadowe. Rekomendowany / niezależny / czyjś kandydat, wyłonić / wystawić kandydata, a także udzielić poparcia kandydatowi to najczęstsze konteksty, w których notowano wówczas ten rzeczownik w polskiej prasie codziennej. ${ }^{21}$

Jak wspomniano przy okazji charakterystyki słów sierpnia, mające się odbyć na jesieni wybory samorządowe już kilka tygodni wcześniej ogniskowały uwagę Polaków. Zanim jednak poszliśmy do urn, w całym kraju odbyły się liczne konwencje wyborcze, podczas których każda partia chciała jak najlepiej zaprezentować swojego kandydata. Niektóre $z$ nich - konkretnie trzy - utworzyły koalicję (Koalicja Obywatelska), której powstanie również wywołało niemałe ogólnospołeczne zamieszanie. Wymienione wydarzenia ze świata polityki i tym razem znalazły odbicie w słownictwie $z$ miesięcznej czołówki frekwencyjnej, we wrześniu tworzonej przez następujace jednostki: wybory, samorzadowy, kandydat, koalicja i konwencja. Mimo dużych emocji dostarczanych w tym czasie przez „aktorów” polskiej sceny politycznej, poruszenie wśród polskich widzów $\mathrm{w}$ drugiej połowie miesiąca wywołała także premiera filmu Wojciecha Smarzowskiego (kolejne słowo września: Kler). Szczęśliwie, gdyż w atmosferze sportowego sukcesu listę leksyki ważnej dziewiątego miesiąca zamknęła pozytywnie kojarzona przez nas siatkówka (obrona tytułu mistrzowskiego na mistrzostwach świata w siatkówce), coraz częściej zresztą nazywana narodowym sportem Polaków. ${ }^{22}$

Nie ma większego zaskoczenia, jeśli chodzi o zakres tematyczny słów października 2018. W związku z odbywającymi się 21. dnia miesiąca wyborami samorządowymi wszystkie pięć wyrazów o największej częstości wystapień w tym okresie to nazwy z kręgu polityki. Oczywiste lek-

20 Jak wyjaśnił Komitet Obrony Demokracji (KOD): „była to forma zamanifestowania naszego przywiazania dla najważniejszych dla nas wartości, a także próba zwrócenia uwagi szerokiej opinii publicznej na fakt, że prezydent Andrzej Duda, mimo licznych protestów obywatelskich, podpisał się pod ustawą zmieniająca Są Najwyższy w kolejna - po Trybunale Konstytucyjnym i Krajowej Radzie Sądowniczej - atrapę". [Polsatnews.pl, 3.08.2018], „KOD „ubrał” kilkadziesiąt pomników w całym kraju w koszulki z napisem „konstytucja” [dostęp: 29.03.2019, <http:/ / www.polsatnews.pl/wiadomosc/2018-08-03/kod-ubralkilkadziesiat-pomnikow-w-calym-kraju-w-koszulki-z-napisem-konstytucja/>].

21 Słowa dnia. Kandydat [dostęp: 29.03.2019, <http:/ / slowadnia.clarin-pl. $\mathrm{eu} /$ \#/search/kandydat/true>].

22 PAKiS. Polska Akademia Kultury i Sportu [28.03.2018, „Siatkówka sportem narodowym Polaków? Duża popularność na kursy dla instruktora piłki siatkowej jest tego dowodem" [dostęp: 31.03.2019, <https://pakis.pl/aktualnosci/siatkowka-sportem-narodowym-polakow-duza-popularnosc-na-kursydlainstruk tora-pilki-siatkowej-jest-tego-dowodem/>]. 
semy - wybory i samorzac - znalazły się w centrum pola $<$ Człowiek a instytucja państwa>. Do podpola 14. <urząd, państwo, polityka> przyporządkowano ponadto rzeczownik koalicja (tu na ogół w połączeniach: lokalna koalicja, koalicje wyborcze, zawiazać koalicję, budowanie koali$\left.c j i^{23}\right)$, który miesiąc wcześniej uznano również za słowo września. Nazwy $z$ innych pól tematycznych, lecz także blisko związane $z$ październikowymi wyborami, to wyraz temporalny tura (pierwsza, druga tura wyborów samorządowych) stanowiący kolejne w prezentowanym zestawieniu zapożyczenie $z$ języka francuskiego ${ }^{24}$ (fr. tour 'obrót' [USJP 2003]) oraz leksem miasto ${ }^{25}$ - w tym roku ogłaszany słowem miesiaca już po raz trzeci (por. kwiecień, maj).

Jedenasty miesiąc ubiegłego roku, $z$ racji przypadajacej w tym czasie setnej rocznicy odzyskania przez Polskę niepodległości, również w mediach upłyną wyjątkowo patriotycznie. Chociaż niepodległośc $c^{26}$ od wielu lat pozostaje słowem listopada ze względu na cykl kulturowy Święta 11 XI i organizowany wówczas w stolicy Marsz Niepodległości, to jubileusz tego doniosłego w historii Polski wydarzenia sprawił, że w listopadzie 2018 roku jeszcze bardziej niż zwykle jako naród przeżywaliśmy te chwile. Zainteresowanie Polaków „goracymi” tematami znalazło odzwierciedlenie w listopadowej leksyce ważnej. Oprócz wspomnianej już niepodległości, która najczęściej pojawiała się w rodzimym przekazie prasowym $\mathrm{w}$ połączeniu $z$ odczasownikowym wyrazem odzyskanie (podpole 17 . <własność>), słowami cyklicznymi $z$ kręgu „niepodległościowego” były też rzeczowniki: rocznica $z$ podpola 28 . <czas $>$, obchody z podpola 10. <zwyczaje i obyczaje> oraz marsz, reprezentujący podpole 9. <stosunki ogólnospołeczne>. Listopadowe świętowanie zakłócił jednak skandal wokół

23 Słowa dnia. Koalicja [dostęp: 29.03.2019, <http://slowadnia.clarin-pl. eu/\#/search/koalicja/true>].

${ }^{24}$ Analiza genetyczna 71 słów miesiaca 2018 roku wykazała, że w grupie 28 zapożyczeń $z$ języków obcych (39\% całości materiału) zapożyczenia francuskie stanowiły największa grupę wyrazów (11 jednostek). Na drugim miejscu znalazły się germanizmy ( 6 jednostek), na trzecim zapożyczenia $z$ języka łacinskiego (5 jednostek). Pozostałe pożyczki leksykalne pochodziły z języków: angielskiego (2 jednostki), czeskiego (1 jednostka), greckiego (1), hiszpańskiego (1) i włoskiego (1). Duży udział galicyzmów w obrębie badanego słownictwa wynika stąd, że większość terminów specjalistycznych obecnych w tym zbiorze - głównie z zakresu prawa, polityki, ekonomii i bankowości - trafiało do polszczyzny właśnie $z$ języka francuskiego [USJP 2003; WSJP 2007-; WSWO 2017].

25 „Miasto” jest też przeciwieństwem domu - wychodzimy „na miasto” w poszukiwaniu rozrywek, „do miasta” po sprawunki, jemy „na mieście”, czyli poza domem”, Derwojedowa [10.12.2018, „Plebiscyt „Słowo roku 2018”: październik - MIASTO, dostęp: 29.03.2019, <http://www.slowanaczasie.uw.edu.pl/plebiscyt-slowo-roku-2018-pazdziernik-miasto/>].

26 M.in. słowo listopada 2015, Derwojedowa [11.12.2018, „Plebiscyt "Słowo roku 2018": listopad - NADZÓR”, dostęp: 29.03.2019, <http://www.slowanaczasie.uw.edu.pl/plebiscyt-slowo-roku-2018-listopad-nadzor/>]. 
Komisji Nadzoru Finansowego (KNF), co po raz kolejny bezpośrednio przełożyło się na język polskich mediów (kolejne słowa listopada 2018 to afera i nadzór). Innym przykładem tego, jak jednostkowe, okazjonalne zajście wpływa na zwiększenie się frekwencji pewnych słów w danym miesiącu, jest rosyjska blokada Cieśniny Kerczeńskiej. W ostatnim tygodniu listopada cały świat „ży” rosyjskim atakiem na ukraińskie statki na Morzu Czarnym. Ów konflikt wyraźnie poruszył mieszkańców kraju nad Wisła, o czym świadczy fakt, iż na polską listę słów listopada trafił rzeczownik cieśnina ${ }^{27}$ - jedyna nazwa wśród jesiennych słów miesiąca przypisana do pola $<$ Człowiek a przyroda $>$.

Grudzień to niezmiennie czas kojarzony przede wszystkim ze świętami i zabawa sylwestrowa. Ostatni miesiac 2018 roku charakteryzował się największą liczbą słów miesiąca - warszawscy językoznawcy wyłonili ich aż dziesięć. Wśród tych nazw zdecydowanie dominowała leksyka $z$ podpola 10. <zwyczaje i obyczaje> (Boże Narodzenie, choinka, Święta, Wigilia). Cyklicznie, gdyż co roku o tej samej porze, na czołówkach list frekwencyjnych występuje też Sylwester (lub sylwester), wyraz z podpola 11 . <rozrywka, zabawa>, który coraz częściej w przekazie medialnym pojawia się w kontekście miejskich i wielkomiejskich imprez masowych. ${ }^{28}$ Istotnym wydarzeniem omawianego miesiąca był również międzynarodowy szczyt klimatyczny ONZ w Katowicach. Ten trwajacy prawie dwa tygodnie zjazd przedstawicieli dwustu państw odbywający się w stolicy Śląska sprawił, że rzeczownik klimat oraz derywowany od niego przymiotnik klimatyczny okazjonalnie poszerzyły zbiór „tradycyjnych” słów grudnia. Trudno wyobrazić sobie listę słów ważnych któregokolwiek $z$ miesięcy bez słownictwa tematycznie zwiąanego $z$ życiem społecznym, ekonomią i polityką. Jeśli chodzi o grudzień 2018 roku, to szczególną uwagę media poświęcały „społecznemu” protestowi tzw. żółtych kamizelek w Paryżu i w Brukseli (por. kamizelka). Ostatnie dwa leksemy zamykajace miniony grudzień, o których także należy wspomnieć, to bonifikata i użytkowanie wieczyste - obydwie jednostki pochodza $z$ podpola 17. <własność> i we współczesnej polszczyźnie reprezentuja grupę słownictwa specjalistycznego $z$ zakresu prawa cywilnego [USJP 2003].

27 Śpiechowicz [25.11.2018, Radio Zet. Wiadomości, „Rosja otworzyła ogień do ukraińskich okrętów. Sa ranni”, dostęp: 30.03.2019, <https://wiadomosci. radiozet.pl/Swiat/Ukraina-Rosja-otworzyla-ogien-do-ukrainskich-okretow-wCiesninie-Kerczenskiej>].

28 Stowa dnia. Sylwester [dostęp 29.03.2019, <http://slowadnia.clarin-pl. eu/\#/search/sylwester/true>]. 


\section{PODSUMOWANIE}

Zasadniczym celem pracy było sprawdzenie, jak przedstawia się struktura tematyczna słów miesiaca polskiej prasy codziennej wyłonionych w 2018 roku. Choć skupienie badawcze dotyczyło przede wszystkim zakresu znaczeniowego wyekscerpowanych leksemów i ograniczało się wyłącznie do materiału $z$ dwunastu miesięcy jednego roku, to wyniki $z$ tak przeprowadzonej analizy można uznać za reprezentatywne dla ogółu rodzimego słownictwa o „zwiększonej kluczowości”. Okazuje się bowiem, że tezy językoznawców, już od kilkunastu lat śledzących leksykalne listy frekwencyjne krajowych przekazów medialnych, znajduja potwierdzenie w sformułowanych dotąd wnioskach. Jeśli chodzi o rozkład tematyczny 71 słów miesiaca 2018 roku, które łącznie $z$ powtórzeniami niektórych leksemów wystapiły w tej kategorii 78 razy, to należy przyznać rację M. Łazińskiemu. Badacz polskich słów o największej częstotliwości podkreślał wielokrotnie, że tym, co najbardziej interesuje Polaków w każdym roku, sa sprawy polityczno-społeczne, a dopiero w dalszej kolejności - kwestie kulturalne czy religijne [Łaziński 2015a, b]. Analiza znaczeniowa zgromadzonego słownictwa wykazała, że w obrębie przyjętej klasyfikacji pola najliczniejsze to te grupujące nazwy związane $z$ państwem i polityka (por. $<$ Człowiek a instytucja państwa $>-31 \%$ całości materiału), a także nazwy ukazujące człowieka jako jednostkę społeczną (por. $<$ Człowiek w społeczności $>-28 \%$ ). Jak ilustruje załączona tabela, strukturę wymienionych pól wyrazowych cechuje również największa liczba podpól, co świadczy zarówno o dużym uszczegółowieniu tematycznym tych zbiorów, jak i o stałym przyroście leksyki wypełniającej wskazane podkręgi. W porównaniu z polami „polityczno-społecznymi” o największej frekwencji w ogólnym, 12-elementowym zestawieniu, znacznie mniej jednostek leksykalnych zgromadzily pola: „przyrodnicze” i „astronomiczne” ( $<$ Człowiek a przyroda $>-6,5 \%$; $<$ Człowiek a astronomia $>-5,1 \%)$, pole "imponderabiliów" (<Człowiek a imponderabilia bytu> $-6,5 \%)$, a także krag „cielesny” (<Ciało człowieka> - 5,1\%) i „cywilizacyjny” (<Otoczenie cywilizacyjne człowieka> - 5,1\%). Jeszcze rzadziej wśród słów miesiaca 2018 roku zanotowano w polskich przekazach medialnych leksykę dotyczaca edukacji człowieka, jego spraw codziennych oraz pracy (por. pola $<$ Wiedza człowieka>, <Życie codzienne>, <Praca człowieka>). Najmniej, zaledwie po jednej jednostce, zarejestrowano w polach „umysłowym” i „artystycznym” (por. <Psychika człowieka>, <Artystyczna działalność człowieka>). W analizowanym materiale uwidoczniły się ponadto tezy tych badaczy, którzy dowodzili cykliczności pewnych słów [Pawłowski 2015; Pęzik 2015], powracających regularnie na czołówki list frekwencyjnych.

Z czasem astronomicznym np. zwiazane sa nazwy zjawisk przyrodniczych, typowych dla określonych pór roku (por. upał, zaćmienie, sinice, skoczek, himalaista). Czas kulturowy wyznacza z kolei powrót cyklicz- 
nych wydarzeń (a wraz z nimi ich nazw) zwiazanych m.in. z tradycja, rozrywką i obrzędami, które, jak się okazuje, sa bardzo ważne dla Polaków. Wigilia, Święta, Boże Narodzenie, Sylwester to dla większości z nas „czas święty”, o czym świadczy fakt, iż od lat niezmiennie wśród grudniowych słów miesiaca pojawiaja się wspomniane heortonimy. Ze „świętym” czasem kulturowym łaczą się także coroczne obchody upamiętniajace ważne dla naszego narodu momenty historyczne (defilada, rocznica, marsz, $\mathrm{Ma-}$ rzec, niepodległość i in.). Czas polityczny natomiast to w polskich mediach głównie jesienny okres przed- i powyborczy, w którym tzw. leksyka ważna mało zaskakuje pod względem zróżnicowania tematycznego. Od lat na listach frekwencyjnych w tych "goracych" miesiacach występują wybory, kandydat, samorzad i samorzadowy, konwencja oraz koalicja. Na koniec warto nadmienić, że w badanym zbiorze słownictwa zaobserwowano duży udział zapożyczeń z języków obcych, neosemantyzmów i leksyki nieogólnej, nacechowanej (głównie prawniczej i książkowej), a także sporo nazw pochodnych, derywowanych od innych wyrazów. Wymienione spostrzeżenia moga zatem stać się przyczynkiem do podjęcia dalszych, nie mniej ciekawych badań zgłębiajacych naturę słów miesiaca kolejnych lat.

\section{Wykaz zastosowanych skrótów:}

fr. - francuski, książk.- książkowy, og. - ogólny, praw. - prawniczy, wł. - włoski.

\section{Bibliografia}

M. Bańko (red.), 2017, Wielki słownik wyrazów obcych PWN, Warszawa [WSWO 2017].

S. Dubisz, 2005, Język - Historia - Kultura (wykłady, studia, analizy), t. 1, Warszawa.

S. Dubisz, 1999, Zróżnicowanie słownictwa współczesnej polszczyzny [w:] S. Dubisz (red.), Nauka o języku dla polonistów, Warszawa, s. 355-374.

A. Markowski, 1990, Leksyka wspólna różnym odmianom polszczyzny, t. 1-2, Warszawa.

A. Markowski, 2012, Wykłady z leksykologii, Warszawa.

\section{Źródla internetowe}

M. Łaziński, 2015a, Słowa klucze - pamięć społeczna $w$ zwierciadle frekwencji, Sympozjum „Słowa roku i słowa klucze”, Uniwersytet Warszawski, 26.10.2015 [prezentacja multimedialna, dostęp: 25.03.2019, <http:/ /www. slowanaczasie.uw.edu.pl/wp-content/uploads/SlowaML.pdf>].

M. Łaziński, 2015b, Słowa klucze prasy polskiej. Słowa dnia i słowa roku UW [dokument pdf, dostęp: 26.03.2019, <http:/ /www.slowanaczasie.uw.edu.pl/ wp-content/uploads/klucze.pdf>]. 
A. Pawłowski, 2015, Modele sekwencji częstości leksemów w prasie na materiale Korpusu ChronoPress. Sympozjum „Słowa roku i słowa klucze”, Uniwersytet Warszawski, 26.10.2015 [prezentacja multimedialna, dostęp: 23.03.2019, <http:/ /www.slowanaczasie.uw.edu.pl/wp-content/uploads/S\%C5\%82owanaczasie_2015_Paw\%C5\%82owski.pdf>].

P. Pęzik, 2015, O cyklach frekwencyjnych niektórych słów i wyrażeń $w$ latach 2010-2015. Sympozjum „Słowa roku i słowa klucze”, Uniwersytet Warszawski, 26.10.2015 [prezentacja multimedialna, dostęp: 26.03.2019, <http:// www.slowanaczasie.uw.edu.pl/wp-content/uploads/pezik_slowa.pdf>].

\section{Inne strony $i$ serwisy internetowe}

Frazeo.pl, dostęp: 26.03.2019, <http:/ / frazeo.pl/>.

PAKiS, dostęp: 31.03.2019, <https://pakis.pl/aktualnosci/>.

Polsatnews.pl, dostęp: 29.03.2019, <http://www.polsatnews.pl/>.

Radio Zet. Wiadomości, dostęp: 30.03.2019, <https://wiadomosci.radiozet.pl/> Słowa dnia, dostęp: 26.03.2019, <http:/ / slowadnia.clarin-pl.eu>.

Słowa dnia (Facebook), dostęp: 26.03.2019, <https://www.facebook.com/SlowaDnia>.

Słowa na czasie, dostęp: 26.03.2019, <www.slowanaczasie.uw.edu.pl>.

S. Dubisz (red. nauk.), Uniwersalny słownik języka polskiego, Warszawa 2003, <https://usjp.pwn.pl/> [dostęp: 27.03.2019 (USJP 2003)].

P. Żmigrodzki (red.), Wielki słownik języka polskiego, Kraków 2007-, <https:// wsjp.pl/index.php?pwh=0> [dostęp: 27.03.2019 (WSJP 2007-)].

Wyborcza.pl, dostęp: 29.03.2019, <http://wyborcza.pl/0,0.html>.

\section{Words of the month in 2018 in lexical and semantic fields}

\section{Summary}

The aim of this study is to present the results of a lexical and semantic analysis of the so-called words of the month in 2018, that is words (or their combinations) with high frequency in the Polish daily press, published and commented by a group of linguists from the Institute of Polish Language, University of Warsaw, on www.slowanaczasie.uw.edu.pl over the past year. Apart from the analysis of the thematic structure of the excerpted lexemes and their assignment to contextually determined word fields, the examination covers the total number of occurrences of the units in the monthly list of words of the month. The outcome of the linguistic analysis not only permitted identification of the most topical issues for Poles in a given year, but also enabled verification of the conclusions drawn by various researchers of cyclic words to date. They have found, among others, a considerable share of borrowings from foreign languages, neologisms and neosemantisms, pointed to a seasonal motivation of the units, and argued that the greatest share in the set belonged to names related to politics, economics, and broadly understood social issues.

Trans. Monika Czarnecka 